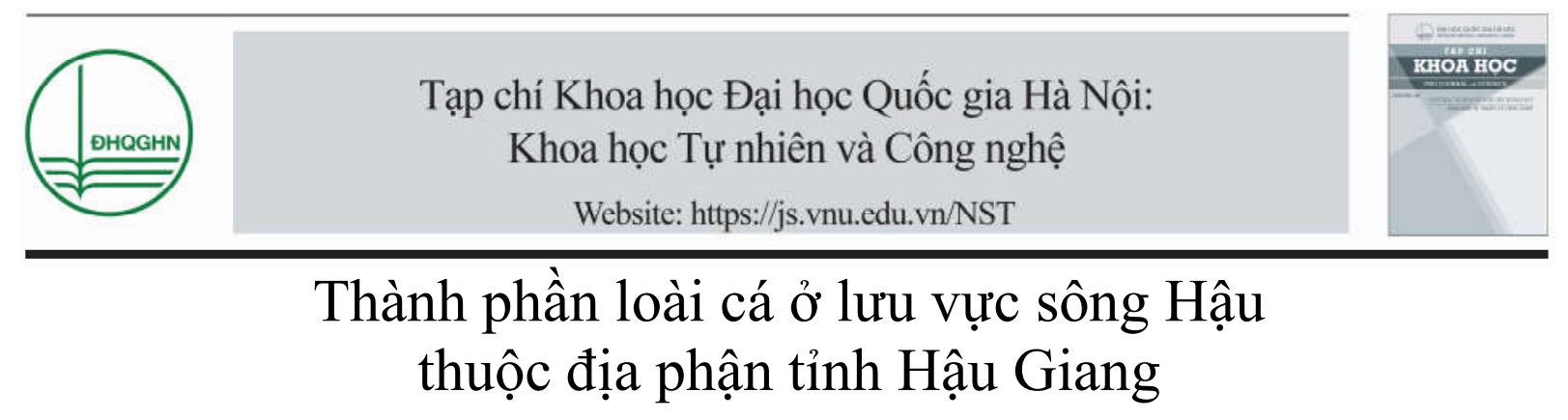

Lê Kim Ngọc ${ }^{1}$, Sơn Ngọc Huyền ${ }^{1}$, Nguyễn Thị Ngọc Huệ̣ ${ }^{1}$, Lê Hoàng $A_{n h}{ }^{1}$, Trần Văn Đẹp ${ }^{1}$, Nguyễn Thành Đông ${ }^{1}$, Trần Đắc Định ${ }^{2}$, Hà Phước Hùng ${ }^{2}$, Tô Thị Mỹ Hoàng ${ }^{2}$, Nguyễn Thị Vàng ${ }^{2}$, Võ Thành Toàn ${ }^{2}$, Nguyễn Trung Tín ${ }^{2}$, Đinh Minh Quang ${ }^{3, *}$

\author{
${ }^{I}$ Chi cuc thủy sản, Sở Nông nghiệp và Phát triển nông thôn tỉnh Hậu Giang \\ ${ }^{2} B$ ộ môn Quản lý và Kinh tế nghề cá, Khoa Thủy sản, Truờng Đại học Cần Tho' \\ ${ }^{3}$ Bộ môn Sinh học, Khoa Su pham, Trưòng Đại học Cần Tho
}

Tóm tắt: Nghiên cứu này được thực hiện trong suốt 1 năm từ tháng 12/2015 đến tháng 11/2016 tại 44 điểm nghiên cứu ở lưu vực sông Hậu thuộc địa phận tỉnh Hậu Giang. Kết quả phân tích đã định danh được 125 loài cá thuộc 19 bộ và 46 họ. Thành phần loài cá ở khu vực nghiên cứu đa dạng hơn vào mùa mưa (119 loài) so với mùa khô (101 loài). Trong 19 bộ cá ghi nhận được thì Bộ cá vược (Perciformes), Bộ cá chép (Cypriniformes) và Bộ cá nheo (Siluriformes) có số lượng loài nhiều nhất trong cả mùa mưa và mùa khô. Kết quả cũng cho thấy giữa ba vùng sinh thái thì vùng chịu ảnh hưởng của thủy triều biển Đông có thành phần loài cao hơn so với vùng chịu ảnh hưởng của thủy triều biển Tây và vùng tiếp giáp giữa 2 vùng trên.

Tù khóa: Hậu Giang, sông Hậu, thành phần loài cá.

\section{1. Đặt vấn đề}

Đồng bằng sông Cửu Long (ĐBSCL) có rất nhiều công trình nghiên cứu về thành phần loài, đánh giá hiện trạng nguồn lợi và tình hình khai thác thuỷ sản cụ thể trong khu vực có 175 loài cá thuộc 109 giống, 48 họ, 17 bộ, trong đó 74\% thuộc nhóm cá trẳng, $7 \%$ thuộc nhóm cá đen, $11 \%$ thuộc nhóm cá nước lợ và $7 \%$ cá nước mặn [1]. Theo Mai Đình Yền và nnk. (1992)

\footnotetext{
*Tác giả liên hệ. ĐT.: 84-907256705.

Email: dmquang@ctu.edu.vn

https://doi.org/10.25073/2588-1140/vnunst.4723
}

[2], khu hệ sinh thái nước ngọt Nam bộ có 255 loài trong 139 giống thuộc 43 họ và 14 bộ; trong khi đó, theo Trương Thủ Khoa \& Trần Thị Thu Hương (1993) [3], khu hệ cá ĐBSCL có 137 loài; và theo Đoàn Văn Tiến \& Mai Thị Trúc Chi (2005) [4], ở ĐBSCL có 193 loài thuộc 40 họ và 13 bộ được ghi nhận. Gần đây nhất, Trần Đắc Định và nnk. (2013) [5] đã định loại được 322 loài cá, trong đó có 312 loài thu được trong vùng nước ngọt và lợ, và có 10 loài cá biển thu được ở vùng cửa sông ĐBSCL. Các kết quả nghiên cứu trên cho thấy có sự khác biệt về số lượng loài giữa các tác giả khi khảo 
sát về nguồn lợi thuỷ sản trong khu vực ĐBSCL.

Hậu Giang là tỉnh nội đồng, nằm ở trung tâm của Đồng bằng sông Cửu Long. Phía Bắc giáp Thành phố Cần Thơ, phía Tây giáp tỉnh Kiên Giang, phía Tây Nam giáp tỉnh Bạc Liêu, phía Đông giáp tỉnh Sóc Trăng, phía Đông Bắc giáp sông Hậu. Diện tích tự nhiên toàn tỉnh là 160.245 ha, được chia làm 03 vùng sinh thái đặc trưng là vùng ảnh hưởng của triều biển Đông, vùng ảnh hưởng của triều biển Tây và vùng ảnh hưởng thủy triều biển kết hợp. Hệ thống sông ngòi chằng chịt với tổng chiều dài khoảng $3.584 \mathrm{~km}$, trong đó có 27 kênh cấp I với tổng chiều dài là $598,15 \mathrm{~km}, 266$ kênh cấp II với tổng chiều dài là $1.311,5 \mathrm{~km}$ và 558 kênh cấp III với tổng chiều dài là $1.674,508 \mathrm{~km}$ [6]. Nguồn lợi thủy sản tự nhiên đa dạng, phong phú, tuy nhiên, trong vài năm gần đây nguồn lợi thủy sản ngoài tự nhiên có biểu hiện giảm sút đáng kể, số loài có giá trị kinh tế dần cạn kiệt, thậm chí có một số loài có nguy cơ tuyệt chủng. Nguyên nhân gây suy giảm nguồn lợi chủ yếu là do việc khai thác không hợp lý, chẳng hạn như tình trạng sử dụng xung điện, kích thước mắt lưới nhỏ để khai thác thủy sản...; ô nhiễm môi trường, phá huỷ môi trường sống và nơi sinh sản của các loài thuỷ sản. Nguồn lợi thủy sản ngày càng suy giảm làm mất đi sự cân bằng của hệ sinh thái ảnh hưởng đến kinh tế, xã hội của tỉnh. Mục tiêu quan trọng của công tác quản lý nghề cá là phải đảm bảo cho hệ sinh thái phát triển bền vững, đồng thời duy trì trữ lượng tối thiểu cho từng loài. Để có được một hệ sinh thái bền vững, khai thác ổn định nguồn lợi trong hệ sinh thái đó, điều quan trọng là phải duy trì tính đa dạng về thành phần loài.

Tuy nhiên, với vùng sinh thái đặc trưng đó của tỉnh Hậu Giang vẫn chưa có công trình nghiên cứu về thành phần loài, cũng như nghiên cứu đánh giá biến động nguồn lợi thủy sản để có biện pháp khai thác, bảo vệ và tái tạo hợp lý. Vì vậy, nghiên cứu này được thực hiện nhằm đánh giá lại thành phần loài cá ở lưu vực sông Hậu thuộc địa phận tỉnh Hậu Giang. Kết quả của đề tài sẽ bổ sung dẫn liệu về thành phần loài cá nước ngọt cho ĐBCSL và Việt Nam cũng như là cơ sở cho việc đề xuất chiến lược khai thác hợp lý và bền vững nguồn lợi thủy sản trên toàn tỉnh.

\section{Phương tiện và phương pháp nghiên cứu}

\subsection{Phưong pháp chọn điểm thu mẫu}

Khảo sát các vùng sinh thái (vùng ảnh hưởng của triều biển Đông - vùng I, vùng ảnh hưởng của triều biển Tây - vùng II và vùng ảnh hưởng kết hợp giữa triều biển Đông và triều biển Tây - vùng III), các loại hình thủy vực trên địa bàn tỉnh Hậu Giang (sông, kênh, rạch, đồng ruộng,...) và lựa chọn khu vực thu mẫu phù hợp, đại diện cho đặc trưng của từng vùng sinh thái và từng loại hình thủy vực. Cụ thể:

- Theo tuyến sông lớn: chọn 07 tuyến sông, kênh cấp 1 , cụ thể thu mẫu trển các tuyến sông sau: sông Hậu đoạn chảy qua địa bàn huyện Châu Thành, sông Cái Lớn - kênh Xáng Xà No, sông Nước Đục, sông Cái Trầu, sông Ba Láng, kênh Xáng Nàng Mau và kênh Xáng Cái Côn. Mỗi tuyến chọn 03 vị trí để thu mẫu (đầu, giữa và cuối tuyến). Như vậy theo tuyến sông lớn xác định được 21 điểm thu mẫu.

- Theo vùng sinh thái: căn cứ trên bản đồ chia tỉnh Hậu Giang thành 6 mặt cắt, mỗi mặt cắt thu từ 2-3 điểm. Như vậy, theo vùng sinh thái sẽ xác định được 15 điểm, trong đó vùng I có 4 điểm thu mẫu gồm kênh Cái Cui (huyện Châu Thành), sông Phú Hữu (huyện Châu Thành), kênh Xẻo Vong (Thị xã Ngã Bảy) và kênh Trầu Hôi (huyện Châu Thành $\mathrm{A}$ ); vùng II có 8 điểm thu mẫu gồm kênh Thầy Năm (huyện Long Mỹ), kênh Long Điền (huyện Vị Thủy), kênh 13000 (huyện Vị Thủy), kênh Tắc (Thành phố Vị Thanh), kênh Lý Nết (Thị xã Long Mỹ), kênh Nhật Tảo (Thị xã Long Mỹ), sông Nước Trong (huyện Long Mỹ) và kênh Năm (Tp.Vị Thanh); vùng III có 3 điểm thu mẫu gồm kênh 4000 (huyện Châu Thành A), kênh 8000 (huyện Phụng Hiệp) và kênh Long Phụng (huyện Phụng Hiệp) (Hình 1). 


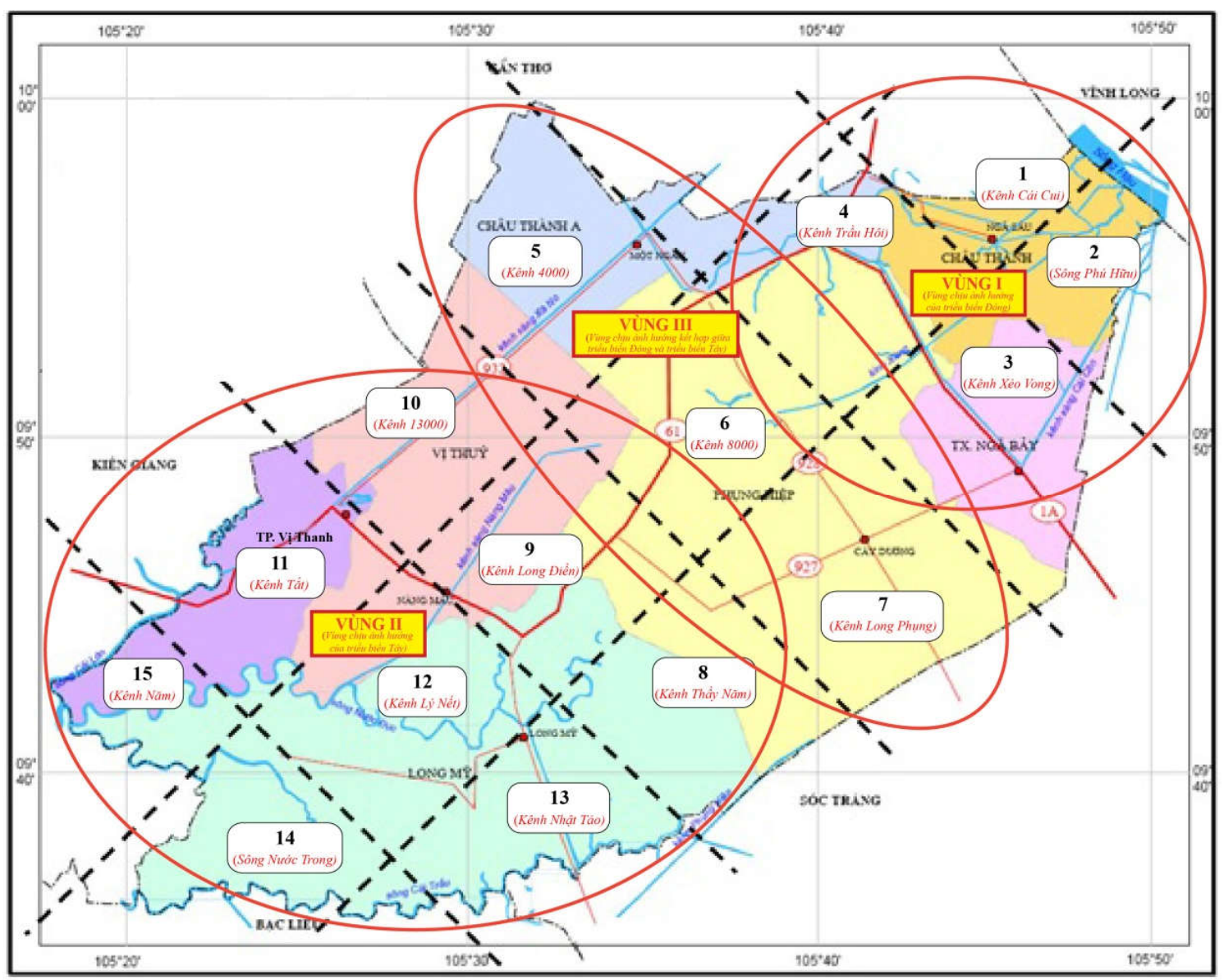

Hình 1. Các điểm thu mẫu theo vùng sinh thái trên địa bàn tỉnh Hậu Giang.

Bên cạnh việc thu mẫu trên các sông, kênh rạch và đồng ruộng, còn thu mẫu tại các điểm chợ; chọn mỗi huyện, thị, thành phố 01 chợ để thu mẫu. Như vậy sẽ thu mẫu tại 8 chợ có mua bán thủy sản gồm chợ Phường 3 (khu chợ nông thôn) - Thành phố Vị Thanh, chợ Nàng Mau huyện Vị Thủy, chợ Thuận An - Thị xã Long Mỹ, chợ Lương Nghĩa - huyện Long Mỹ, chọ Cây Dương - huyện Phụng Hiệp, chợ Bảy ngàn - huyện Châu Thành $\mathrm{A}$, chợ Ngã Sáu - huyện Châu Thành và chợ Ngã Bảy - Thị xã Ngã Bảy.

Như vậy tổng số điểm thu mẫu là 44 điểm.

\subsection{Phrơng pháp thu mẫu cá}

- Địa điểm: tiến hành thu mẫu tại các vị trí được lựa chọn đã nêu ở trên (44 điểm/đợt).
- Thời gian và tần suất thu mẫu: mẫu được thu trong vòng 01 năm, vào mùa mưa và mùa khô, định kỳ 2 tháng thu một lần. Tại các điểm đã được chọn, nhóm thực hiện sẽ tiến hành thu mua mẫu cá của những người đi đánh bắt bằng các loại ngư cụ khác nhau (lưới cào, lưới rê, chài, đăng, vó, dớn, lọp, trúm...) để có thể thu được số lượng loài cá nhiều nhất. Dụng cụ, hóa chất bảo quản, trữ mẫu: Thùng trữ lạnh, sục khí, formaldehyde và cồn [7].

- Mỗi mẫu thu được ghi chú một số thông tin như nơi khai thác, ngày tháng năm khai thác, phương tiện và dụng cụ đánh bắt, kích thước mắt lưới. Đối với mẫu cá còn sống sau khi thu được, sẽ được chứa trong các xô nước sạch có chạy máy sục khí liên tục để cung cấp oxy; nếu mẫu đã chết, cho mẫu vào các túi nilon rồi đặt vào thùng trữ lạnh [7]. 


\subsection{Phuoong pháp phân tích mẫu}

Việc phân tích và định loại mẫu vật được thực hiện dựa trên phương pháp nghiên cứu của Pravdin (1973) [8]. Cụ thể,

- Toàn bộ mẫu thu được sẽ chuyển về phòng phân tích để định danh và chụp ảnh.

- Phân tích định danh loài dựa vào việc quan sát, cân, đo, đếm các chỉ tiêu hình thái và đối chiếu với các tài liệu nghiên cứu về định loại để xác định tên bộ, họ, giống, loài. Cụ thể:

+ Quan sát hình dạng và màu sắc toàn thân, các cơ quan trên cơ thể cá như miệng, mắt, mũi, râu, khe mang, vây, cơ quan đường bên.

+ Đo các chỉ tiêu về chiều dài và chiều cao như chiều dài tổng cộng, chiều dài chuẩn, chiều dài đầu, chiều cao thân, chiều cao cuống đuôi, khoảng cách giữa hai mắt.

+ Đếm tia vây lưng, vây ngực, vây bụng, vây hậu môn; và đếm vẩy đường bên, vầy cuống đuôi.

- Tài liệu dùng cho định loại: Mai Đình Yên và nnk. (1992) [2], Trương Thủ Khoa \& Trần Thị Thu Hương (1993) [3], Rainboth
(1996) [12], Nguyễn Văn Hảo \& Ngô Sỹ Vân (2001) [9], Nguyễn Văn Hảo (2005) [10] và Nguyễn Văn Hảo (2005) [11], Trần Đắc Định và nnk. (2013) [5], và Eschmeyer \& Fong (2018) [14].

\subsection{Phưong pháp bảo quản mẫu}

- Mẫu sau khi định danh được cố định trong formaldehyde $5-10 \%$ trong thời gian 7-10 ngày. Sau đó, mẫu được rửa sạch và cố định lại trong cồn $50 \%$ trong thời gian $5-7$ ngày trước khi chuyển sang dung dịch cồn $75 \%$ để bảo quản lâu dài. Để giữ mẫu được lâu, trong năm đầu tiên cứ mỗi 3-6 tháng tiến hành thay dung dịch cồn một lần. Thời gian sau đó chỉ cần bồ sung thêm cồn khi dung dịch bị bốc hơi dựa trên phương pháp nghiên cứu của Phạm Nhật và nnk. (2003) [7].

\section{Kết quả và thảo luận}

Sau 6 đợt thu mẫu, nhóm nghiên cứu đã phân tích được 125 loài cá thuộc 19 bộ được thể hiện ở Bảng 1.

Bảng 1. Thành phần loài cá thu được ở khu vực nghiên cứu từ 12/2015 đến 11/2016

\begin{tabular}{|c|c|c|c|c|c|c|c|c|}
\hline STT & $\begin{array}{l}\text { TÊN TIÊNG } \\
\text { VIẸT }\end{array}$ & TÊN KHOA HỌC & $\begin{array}{l}\text { Đợt } 1 \\
\text { Tháng } \\
12 / 20 \\
15\end{array}$ & $\begin{array}{l}\text { Đợt } 2 \\
\text { Tháng } \\
02 / 20 \\
16\end{array}$ & $\begin{array}{l}\text { Đợt } 3 \\
\text { Tháng } \\
04 / 20 \\
16\end{array}$ & $\begin{array}{l}\text { Đợt } 4 \\
\text { Tháng } \\
06 / 20 \\
16\end{array}$ & $\begin{array}{l}\text { Đợt } 5 \\
\text { Tháng } \\
08 / 20 \\
16\end{array}$ & $\begin{array}{l}\text { Đợt } 6 \\
\text { Tháng } \\
10 / 20 \\
16\end{array}$ \\
\hline I & BỘ CÁ CHİNH & ANGUILLIIFORMES & & & & & & \\
\hline 1 & Họ cá chình rắn & Ophichthidae & & & & & & \\
\hline 1 & Cá chình rắn & $\begin{array}{l}\text { Ophichthus rutidoderma } \\
\text { (Bleeker, 1853) }\end{array}$ & & & + & + & & + \\
\hline 2 & Lịch củ & $\begin{array}{l}\text { Pisodonophis boro } \\
\text { (Hamilton, 1822) }\end{array}$ & & & & + & & + \\
\hline II & $\begin{array}{l}\text { BỒ CÁ THÁT } \\
\text { LÁT }\end{array}$ & OSTEOGLOSSIFORMES & & & & & & \\
\hline 2 & Họ cá thát lát & Notopteridae & & & & & & \\
\hline 3 & Cá thát lát & $\begin{array}{l}\text { Notopterus notopterus } \\
\text { (Pallas, 1769) }\end{array}$ & $\begin{array}{l}++++ \\
+\end{array}$ & $\begin{array}{l}++++ \\
+\end{array}$ & $\begin{array}{l}++++ \\
+ \\
\end{array}$ & $\begin{array}{l}++++ \\
+ \\
\end{array}$ & $\begin{array}{l}++++ \\
+ \\
\end{array}$ & $\begin{array}{l}++++ \\
+\end{array}$ \\
\hline 4 & Cá thát lát còm & $\begin{array}{l}\text { Chitala ornata (Gray, } \\
1831 \text { ) }\end{array}$ & + & + & ++ & + & $\begin{array}{l}++++ \\
+ \\
\end{array}$ & +++ \\
\hline III & BỘ CÁ TRÍCH & CLUPEIFORMES & & & & & & \\
\hline 3 & Họ cá trích & Clupeidae & & & & & & \\
\hline 5 & Cá mai & $\begin{array}{l}\text { Escualosa thoracata } \\
\text { (Valenciennes, 1847) }\end{array}$ & & & + & & & \\
\hline
\end{tabular}


94 L.K. Ngọ và nnk. / Tạp chí Khoa học ĐHQGHN: Khoa học Tụ nhiên và Công nghệ, Tập 34, Số 1 (2018) 90-104

\begin{tabular}{|c|c|c|c|c|c|c|c|c|}
\hline STT & $\begin{array}{l}\text { TÊN TIẾNG } \\
\text { VIẸT }\end{array}$ & TÊN KHOA HỌC & $\begin{array}{l}\text { Đợt } 1 \\
\text { Tháng } \\
12 / 20 \\
15\end{array}$ & $\begin{array}{l}\text { Đợt } 2 \\
\text { Tháng } \\
02 / 20 \\
16\end{array}$ & $\begin{array}{l}\text { Đợt } 3 \\
\text { Tháng } \\
04 / 20 \\
16\end{array}$ & $\begin{array}{l}\text { Đợt } 4 \\
\text { Tháng } \\
06 / 20 \\
16\end{array}$ & $\begin{array}{l}\text { Đợt } 5 \\
\text { Tháng } \\
08 / 20 \\
16\end{array}$ & $\begin{array}{l}\text { Đợt } 6 \\
\text { Tháng } \\
10 / 20 \\
16\end{array}$ \\
\hline 6 & Cá cơm & $\begin{array}{l}\text { Clupeichthys aesarnensis } \\
\text { Wongratana, } 1983\end{array}$ & $\begin{array}{l}++++ \\
+\end{array}$ & $\begin{array}{l}++++ \\
+\end{array}$ & +++ & ++++ & +++ & +++ \\
\hline 7 & Cá cơm & $\begin{array}{l}\text { Corica laciniata Fowler, } \\
1935\end{array}$ & + & + & + & + & + & + \\
\hline 8 & Cá cơm trích & $\begin{array}{l}\text { Clupeoides borneensis } \\
\text { Bleeker, } 1851\end{array}$ & + & + & ++ & ++ & + & + \\
\hline 4 & Họ cá trỏng & Engraulidae & & & & & & \\
\hline 9 & Cá lành canh & $\begin{array}{l}\text { Coilia lindmani Bleeker, } \\
1857\end{array}$ & & & ++ & + & & + \\
\hline 10 & $\begin{array}{l}\text { Cá tớp xuôi/ cá lẹp } \\
\text { sâu }\end{array}$ & $\begin{array}{l}\text { Lycothrissa } \\
\text { crocodilus (Bleeker, 1850) }\end{array}$ & + & + & + & +++ & ++ & + \\
\hline IV & BỘ CÁ CHÉP & CYPRINIFORMES & & & & & & \\
\hline 5 & Họ cá heo & Botiidae & & & & & & \\
\hline 11 & Cá heo bạc & $\begin{array}{l}\text { Yasuhikotakia lecontei } \\
\text { (Fowler, 1937) }\end{array}$ & & + & & & & \\
\hline 12 & Cá heo vạch & $\begin{array}{l}\text { Yasuhikotakia modesta } \\
\text { (Bleeker, 1864) }\end{array}$ & & & + & + & & \\
\hline 6 & Họ cá heo & Cobitidae & & & & & & \\
\hline 13 & Cá heo râu & $\begin{array}{l}\text { Lepidocephalichthys } \\
\text { hasselti (Valenciennes, } \\
1846 \text { ) }\end{array}$ & + & & & & & \\
\hline 7 & Họ cá chép & Cyprinidae & & & & & & \\
\hline 14 & Cá thiểu mẫu & $\begin{array}{l}\text { Paralaubuca typus } \\
\text { Bleeker, } 1864\end{array}$ & + & + & + & + & + & + \\
\hline 15 & Cá lòng tong sắt & $\begin{array}{l}\text { Esomus metallicus Ahl, } \\
1923\end{array}$ & + & + & + & + & + & + \\
\hline 16 & $\begin{array}{l}\text { Cá lòng tong đuôi } \\
\text { vàng }\end{array}$ & $\begin{array}{l}\text { Rasbora aurotaenia } \\
\text { (Tirant, 1885) }\end{array}$ & $\begin{array}{l}++++ \\
+ \\
\end{array}$ & $\begin{array}{l}++++ \\
+ \\
\end{array}$ & $\begin{array}{l}++++ \\
+\end{array}$ & ++++ & $\begin{array}{l}++++ \\
+ \\
\end{array}$ & ++++ \\
\hline 17 & Cá lòng tong & $\begin{array}{l}\text { Rasbora paviana Tirant, } \\
1885\end{array}$ & $\begin{array}{l}++++ \\
+\end{array}$ & $\begin{array}{l}++++ \\
+\end{array}$ & & + & & ++ \\
\hline 18 & Cá lòng tong & Rasbora sp & & & & + & +++ & ++ \\
\hline 19 & Cá tráo & $\begin{array}{l}\text { Amblypharyngodon } \\
\text { chulabhornae } \\
\text { Vidthayanon \& Kottelat, } \\
1990\end{array}$ & & & + & & & \\
\hline 20 & Cá mè trắng & $\begin{array}{l}\text { Hypophthalmichthys } \\
\text { molitrix (Valenciennes, } \\
\text { 1844) }\end{array}$ & + & + & + & & + & + \\
\hline 21 & Cá mè hoa & $\begin{array}{l}\text { Hypophthalmichthys } \\
\text { nobilis (Richardson, 1845) }\end{array}$ & & & & + & & \\
\hline 22 & Cá ngựa nam & $\begin{array}{l}\text { Hampala dispar Smith, } \\
1934\end{array}$ & ++ & + & + & + & + & + \\
\hline 23 & Cá dảnh & $\begin{array}{l}\text { Puntioplites proctozystron } \\
\text { (Bleeker, 1865) }\end{array}$ & $\begin{array}{l}++++ \\
+ \\
\end{array}$ & $\begin{array}{l}++++ \\
+ \\
\end{array}$ & $\begin{array}{l}++++ \\
+ \\
\end{array}$ & $\begin{array}{l}++++ \\
+ \\
\end{array}$ & $\begin{array}{l}++++ \\
+ \\
\end{array}$ & $\begin{array}{l}++++ \\
+ \\
\end{array}$ \\
\hline 24 & Cá he vàng & $\begin{array}{l}\text { Barbonymus altus } \\
\text { (Günther, 1868) }\end{array}$ & $\begin{array}{l}++++ \\
+ \\
\end{array}$ & $\begin{array}{l}++++ \\
+ \\
\end{array}$ & $\begin{array}{l}++++ \\
+ \\
\end{array}$ & ++++ & $\begin{array}{l}++++ \\
+ \\
\end{array}$ & +++ \\
\hline 25 & Cá mè vinh & $\begin{array}{l}\text { Barbonymus gonionotus } \\
\text { (Bleeker, 1849) }\end{array}$ & $\begin{array}{l}++++ \\
+ \\
\end{array}$ & $\begin{array}{l}++++ \\
+ \\
\end{array}$ & $\begin{array}{l}++++ \\
+ \\
\end{array}$ & $\begin{array}{l}++++ \\
+ \\
\end{array}$ & $\begin{array}{l}++++ \\
+ \\
\end{array}$ & $\begin{array}{l}++++ \\
+ \\
\end{array}$ \\
\hline
\end{tabular}




\begin{tabular}{|c|c|c|c|c|c|c|c|c|}
\hline STT & $\begin{array}{l}\text { TÊN TIẾNG } \\
\text { VIẸT }\end{array}$ & TÊN KHOA HỌC & $\begin{array}{l}\text { Đợt } 1 \\
\text { Tháng } \\
12 / 20 \\
15\end{array}$ & $\begin{array}{l}\text { Đợt } 2 \\
\text { Tháng } \\
02 / 20 \\
16\end{array}$ & $\begin{array}{l}\text { Đợt } 3 \\
\text { Tháng } \\
04 / 20 \\
16\end{array}$ & $\begin{array}{l}\text { Đợt } 4 \\
\text { Tháng } \\
06 / 20 \\
16\end{array}$ & $\begin{array}{l}\text { Đợt } 5 \\
\text { Tháng } \\
08 / 20 \\
16\end{array}$ & $\begin{array}{l}\text { Đợt } 6 \\
\text { Tháng } \\
10 / 20 \\
16\end{array}$ \\
\hline 26 & Cá đỏ mang & $\begin{array}{l}\text { Puntius orphoides } \\
\text { (Valenciennes, 1842) }\end{array}$ & $\begin{array}{l}++++ \\
+\end{array}$ & ++++ & +++ & ++++ & ++++ & ++ \\
\hline 27 & Cá rằm & $\begin{array}{l}\text { Puntius brevis (Bleeker, } \\
1849 \text { ) }\end{array}$ & +++ & ++++ & +++ & ++ & ++++ & ++++ \\
\hline 28 & Cá dảnh giả & $\begin{array}{l}\text { Sikukia stejnegeri Smith, } \\
1931\end{array}$ & & & & & + & + \\
\hline 29 & Cá cóc & $\begin{array}{l}\text { Cyclocheilos enoplos } \\
\text { (Bleeker, 1849) }\end{array}$ & $\begin{array}{l}++++ \\
+\end{array}$ & $\begin{array}{l}++++ \\
+\end{array}$ & ++++ & ++ & + & + \\
\hline 30 & Cá duồng bay & $\begin{array}{l}\text { Cosmochilus harmandi } \\
\text { Sauvage, } 1878\end{array}$ & & & & & + & \\
\hline 31 & Cá trao tráo & $\begin{array}{l}\text { Albulichthys albuloides } \\
\text { (Bleeker, 1855) }\end{array}$ & & & & + & + & + \\
\hline 32 & Cá linh rìa xiêm & $\begin{array}{l}\text { Henicorhynchus siamensis } \\
\text { (Sauvage, 1881) }\end{array}$ & $\begin{array}{l}++++ \\
+\end{array}$ & $\begin{array}{l}++++ \\
+\end{array}$ & $\begin{array}{l}++++ \\
+\end{array}$ & ++ & $\begin{array}{l}++++ \\
+\end{array}$ & ++++ \\
\hline 33 & $\begin{array}{l}\text { Cá linh rìa đuôi } \\
\text { vàng }\end{array}$ & $\begin{array}{l}\text { Henicorhynchus lobatus } \\
\text { Smith, } 1945\end{array}$ & $\begin{array}{l}++++ \\
+\end{array}$ & $\begin{array}{l}++++ \\
+\end{array}$ & $\begin{array}{l}++++ \\
+\end{array}$ & ++ & $\begin{array}{l}++++ \\
+\end{array}$ & $\begin{array}{l}++++ \\
+\end{array}$ \\
\hline 34 & Cá chép & $\begin{array}{l}\text { Cyprinus carpio Linnaeus, } \\
1758\end{array}$ & $\begin{array}{l}++++ \\
+\end{array}$ & $\begin{array}{l}++++ \\
+\end{array}$ & $\begin{array}{l}++++ \\
+\end{array}$ & +++ & $\begin{array}{l}++++ \\
+\end{array}$ & ++ \\
\hline 35 & Cá linh rây & $\begin{array}{l}\text { Labiobarbus leptocheila } \\
\text { (Valenciennes, 1842) }\end{array}$ & ++ & ++ & + & + & + & \\
\hline 36 & Cá trôi & $\begin{array}{l}\text { Labeo rohita (Hamilton, } \\
1822 \text { ) }\end{array}$ & & & & & + & \\
\hline 37 & Cá ét mọi & $\begin{array}{l}\text { Labeo chrysophekadion } \\
\text { (Bleeker, 1849) }\end{array}$ & & & + & + & + & + \\
\hline 38 & $\begin{array}{l}\text { Cá ba kỳ đỏ/cá cóc } \\
\text { đậm }\end{array}$ & $\begin{array}{l}\text { Cyclocheilichthys apogon } \\
\text { (Valenciennes, 1842) }\end{array}$ & ++ & ++ & + & + & & + \\
\hline 39 & Cá trà sóc & $\begin{array}{l}\text { Probarbus jullieni Sauvag } \\
\text { e, } 1880\end{array}$ & & & & ++ & +++ & ++ \\
\hline 40 & Cá trao tráo & $\begin{array}{l}\text { Amblyrhynchichthys } \\
\text { micracanthus } \mathrm{Ng} \mathrm{\&} \\
\text { Kottelat, } 2004\end{array}$ & +++ & +++ & + & + & + & + \\
\hline $\mathrm{V}$ & BỘ CÁ CHIM & CHARACIFORMES & & & & & & \\
\hline 8 & Họ cá chim & Characidae & & & & & & \\
\hline 41 & $\begin{array}{l}\text { Cá chim nước } \\
\text { ngọt }\end{array}$ & $\begin{array}{l}\text { Piaractus brachypomus } \\
\text { (Cuvier, 1818) }\end{array}$ & +++ & +++ & & & & + \\
\hline VI & $\begin{array}{l}\text { BỘ CÁ DA } \\
\text { TROON }\end{array}$ & SILURIFORMES & & & & & & \\
\hline 9 & Họ cá ngát & Plotosidae & & & & & & \\
\hline 42 & Cá ngát & $\begin{array}{l}\text { Plotosus canius Hamilton, } \\
1822\end{array}$ & $\begin{array}{l}++++ \\
+\end{array}$ & $\begin{array}{l}++++ \\
+\end{array}$ & $\begin{array}{l}++++ \\
+\end{array}$ & ++++ & $\begin{array}{l}++++ \\
+\end{array}$ & ++++ \\
\hline 10 & Họ cá ngạnh & Bagridae & & & & & & \\
\hline 43 & Cá chốt giấy & $\begin{array}{l}\text { Mystus albolineatus } \\
\text { Roberts, } 1994\end{array}$ & $\begin{array}{l}++++ \\
+\end{array}$ & $\begin{array}{l}++++ \\
+\end{array}$ & $\begin{array}{l}++++ \\
+\end{array}$ & $\begin{array}{l}++++ \\
+\end{array}$ & $\begin{array}{l}++++ \\
+\end{array}$ & $\begin{array}{l}++++ \\
+\end{array}$ \\
\hline 44 & Cá chốt sọc & $\begin{array}{l}\text { Mystus mysticetus Roberts, } \\
1992\end{array}$ & $\begin{array}{l}++++ \\
+\end{array}$ & $\begin{array}{l}++++ \\
+\end{array}$ & $\begin{array}{l}++++ \\
+\end{array}$ & $\begin{array}{l}++++ \\
+\end{array}$ & $\begin{array}{l}++++ \\
+\end{array}$ & $\begin{array}{l}++++ \\
+\end{array}$ \\
\hline 45 & Cá chốt vàng & Mystus velifer $\mathrm{Ng}, 2012$ & +++ & +++ & +++ & ++++ & ++++ & + \\
\hline 46 & Cá chốt trắng & Mystus gulio (Hamilton, & ++++ & ++++ & ++++ & +++ & ++++ & ++++ \\
\hline
\end{tabular}




\begin{tabular}{|c|c|c|c|c|c|c|c|c|}
\hline STT & $\begin{array}{l}\text { TÊN TIÊNG } \\
\text { VIẸT }\end{array}$ & TÊN KHOA HỌC & $\begin{array}{l}\text { Đợt } 1 \\
\text { Tháng } \\
12 / 20 \\
15\end{array}$ & $\begin{array}{l}\text { Đợt } 2 \\
\text { Tháng } \\
02 / 20 \\
16\end{array}$ & $\begin{array}{l}\text { Đợt } 3 \\
\text { Tháng } \\
04 / 20 \\
16\end{array}$ & $\begin{array}{l}\text { Đợt } 4 \\
\text { Tháng } \\
06 / 20 \\
16\end{array}$ & $\begin{array}{l}\text { Đợt } 5 \\
\text { Tháng } \\
08 / 20 \\
16\end{array}$ & $\begin{array}{l}\text { Đợt } 6 \\
\text { Tháng } \\
10 / 20 \\
16\end{array}$ \\
\hline & & 1822) & + & + & + & & & + \\
\hline 47 & Cá lăng & $\begin{array}{l}\text { Hemibagrus spilopterus } \\
\text { Ng \& Rainboth, } 1999\end{array}$ & $\begin{array}{l}++++ \\
+\end{array}$ & +++ & $\begin{array}{l}++++ \\
+\end{array}$ & $\begin{array}{l}++++ \\
+\end{array}$ & + & + \\
\hline 11 & Họ cá chiên & Akysidae & & & & & & \\
\hline 48 & Cá chiên & $\begin{array}{l}\text { Pseudobagarius filifer (Ng } \\
\text { \& Rainboth, 2005) }\end{array}$ & & & & & + & \\
\hline 49 & Cá chiên & $\begin{array}{l}\text { Pseudobagarius similis } \\
\text { (Ng \& Kottelat, 1998) }\end{array}$ & & & + & & ++ & \\
\hline 12 & Họ Cá Tra & Pangasiidae & & & & & & \\
\hline 50 & Cá xác & $\begin{array}{l}\text { Helicophagus } \\
\text { leptorhynchus } \mathrm{Ng} \& \\
\text { Kottelat, } 2000\end{array}$ & & & & + & & \\
\hline 51 & Cá tra & $\begin{array}{l}\text { Pangasianodon } \\
\text { hypophthalmus (Sauvage, } \\
1878 \text { ) }\end{array}$ & $\begin{array}{l}++++ \\
+\end{array}$ & $\begin{array}{l}++++ \\
+\end{array}$ & $\begin{array}{l}++++ \\
+\end{array}$ & $\begin{array}{l}++++ \\
+\end{array}$ & $\begin{array}{l}++++ \\
+\end{array}$ & $\begin{array}{l}++++ \\
+\end{array}$ \\
\hline 52 & Cá hú & $\begin{array}{l}\text { Pangasius conchophilus } \\
\text { Roberts \& Vidthayanon, } \\
1991\end{array}$ & & & & + & ++++ & + \\
\hline 53 & Cá ba sa & $\begin{array}{l}\text { Pangasius bocourti } \\
\text { Sauvage, } 1880\end{array}$ & $\begin{array}{l}++++ \\
+\end{array}$ & $\begin{array}{l}++++ \\
+\end{array}$ & + & ++++ & +++ & $\begin{array}{l}++++ \\
+\end{array}$ \\
\hline 54 & Cá vồ đém & $\begin{array}{l}\text { Pangasius larnaudii } \\
\text { Bocourt, } 1866\end{array}$ & & + & & + & $\begin{array}{l}++++ \\
+ \\
\end{array}$ & \\
\hline 55 & Cá dứa & $\begin{array}{l}\text { Pangasius elongatus } \\
\text { Pouyaud, Gustiano \& } \\
\text { Teugels, } 2002\end{array}$ & & & & & +++ & + \\
\hline 56 & Cá sát sọc & $\begin{array}{l}\text { Pangasius macronema } \\
\text { Bleeker, } 1850\end{array}$ & $\begin{array}{l}++++ \\
+\end{array}$ & $\begin{array}{l}++++ \\
+\end{array}$ & $\begin{array}{l}++++ \\
+\end{array}$ & $\begin{array}{l}++++ \\
+\end{array}$ & $\begin{array}{l}++++ \\
+\end{array}$ & $\begin{array}{l}++++ \\
+\end{array}$ \\
\hline 13 & Họ cá nheo & Siluridae & & & & & & \\
\hline 57 & Cá kêt/trèn mõ & Phalacronotus spp. & +++ & +++ & ++ & ++++ & +++ & ++ \\
\hline 58 & Cá trèn bầu & $\begin{array}{l}\text { Ompok siluroides } \\
\text { Lacepède, } 1803\end{array}$ & & & + & + & + & \\
\hline 14 & Họ cá trê & Clariidae & & & & & & \\
\hline 59 & Cá trê vàng & $\begin{array}{l}\text { Clarias macrocephalus } \\
\text { Günther, } 1864\end{array}$ & $\begin{array}{l}++++ \\
+\end{array}$ & $\begin{array}{l}++++ \\
+\end{array}$ & ++++ & $\begin{array}{l}++++ \\
+\end{array}$ & $\begin{array}{l}++++ \\
+\end{array}$ & $\begin{array}{l}++++ \\
+\end{array}$ \\
\hline 60 & Cá trê trắng & $\begin{array}{l}\text { Clarias batrachus } \\
\text { (Linnaeus, 1758) }\end{array}$ & $\begin{array}{l}++++ \\
+\end{array}$ & $\begin{array}{l}++++ \\
+\end{array}$ & $\begin{array}{l}++++ \\
+ \\
\end{array}$ & $\begin{array}{l}++++ \\
+ \\
\end{array}$ & $\begin{array}{l}++++ \\
+ \\
\end{array}$ & $\begin{array}{l}++++ \\
+ \\
\end{array}$ \\
\hline 61 & Cá trê lai* & $\begin{array}{l}\text { C. macrocephalus } x C \text {. } \\
\text { gariepinus }\end{array}$ & $\begin{array}{l}++++ \\
+\end{array}$ & $\begin{array}{l}++++ \\
+\end{array}$ & $\begin{array}{l}++++ \\
+ \\
\end{array}$ & $\begin{array}{l}++++ \\
+\end{array}$ & ++++ & $\begin{array}{l}++++ \\
+\end{array}$ \\
\hline 15 & Họ cá úc & Ariidae & & & & & & \\
\hline 62 & Cá úc chấm & $\begin{array}{l}\text { Arius maculatus } \\
\text { (Thunberg, 1792) }\end{array}$ & & & +++ & ++ & ++++ & ++ \\
\hline 63 & Cá úc nghệ & $\begin{array}{l}\text { Arius venosus } \\
\text { Valenciennes, } 1840\end{array}$ & & & & + & + & + \\
\hline 64 & Cá úc mím & $\begin{array}{l}\text { Cephalocassis borneensis } \\
\text { (Bleeker, 1851) }\end{array}$ & + & + & ++ & +++ & + & \\
\hline 65 & Cá úc đầu dẹp & $\begin{array}{l}\text { Cryptarius truncatus } \\
\text { (Valenciennes,1840) }\end{array}$ & & & + & + & + & + \\
\hline
\end{tabular}




\begin{tabular}{|c|c|c|c|c|c|c|c|c|}
\hline STT & $\begin{array}{l}\text { TÊN TIÊNG } \\
\text { VIẸT }\end{array}$ & TÊN KHOA HỌC & $\begin{array}{l}\text { Đợt } 1 \\
\text { Tháng } \\
12 / 20 \\
15\end{array}$ & $\begin{array}{l}\text { Đợt } 2 \\
\text { Tháng } \\
02 / 20 \\
16\end{array}$ & $\begin{array}{l}\text { Đợt } 3 \\
\text { Tháng } \\
04 / 20 \\
16\end{array}$ & $\begin{array}{l}\text { Đợt } 4 \\
\text { Tháng } \\
06 / 20 \\
16\end{array}$ & $\begin{array}{l}\text { Đợt } 5 \\
\text { Tháng } \\
08 / 20 \\
16\end{array}$ & $\begin{array}{l}\text { Đợt } 6 \\
\text { Tháng } \\
10 / 20 \\
16\end{array}$ \\
\hline 16 & Họ cá lau kiếng & Loricariidae & & & & & & \\
\hline 66 & Cá lau kiếng & \begin{tabular}{|l} 
Pterygoplichthys \\
disjunctivus (Weber, 1991)
\end{tabular} & $\begin{array}{l}++++ \\
+\end{array}$ & $\begin{array}{l}++++ \\
+\end{array}$ & $\begin{array}{l}++++ \\
+\end{array}$ & $\begin{array}{l}++++ \\
+\end{array}$ & $\begin{array}{l}++++ \\
+\end{array}$ & $\begin{array}{l}++++ \\
+\end{array}$ \\
\hline VII & $\begin{array}{l}\text { BỘ CÁ HÀM } \\
\text { ÉCH }\end{array}$ & BATRACHOIDIFORMES & & & & & & \\
\hline 17 & Họ cá hàm ếch & Batrachoididae & & & & & & \\
\hline 67 & Cá hàm ếch & $\begin{array}{l}\text { Allenbatrachus grunniens } \\
\text { (Linnaeus, 1758) }\end{array}$ & & & ++++ & + & & + \\
\hline VIII & $\begin{array}{l}\text { BỘ CÁ THU } \\
\text { NGƯ }\end{array}$ & SCOMBRIFORMES & & & & & & \\
\hline 18 & Họ cá bạc má & Scombridae & & & & & & \\
\hline 68 & Cá thu sông & $\begin{array}{l}\text { Scomberomorus sinensis } \\
\text { (Lacepède, 1800) }\end{array}$ & & & & + & & \\
\hline IX & $\begin{array}{l}\text { BỘ CÁ CHİA } \\
\text { VỒI }\end{array}$ & SYNGNATHIFORMES & & & & & & \\
\hline 19 & Họ cá chìa vôi & Syngnathidae & & & & & & \\
\hline 69 & Cá ngựa xương & $\begin{array}{l}\text { Doryichthys boaja } \\
\text { (Bleeker, 1850) }\end{array}$ & & & + & & & \\
\hline $\mathrm{X}$ & BỘ CÁ BỐNG & GOBIIFORMES & & & & & & \\
\hline 20 & Họ cá bống đen & Eleotridae & & & & & & \\
\hline 70 & Cá bống trân & $\begin{array}{l}\text { Butis butis (Hamilton, } \\
\text { 1822) }\end{array}$ & & + & + & & ++++ & + \\
\hline 71 & Cá bống trứng & $\begin{array}{l}\text { Eleotris melanosoma } \\
\text { Bleeker, } 1853\end{array}$ & $\begin{array}{l}++++ \\
+\end{array}$ & $\begin{array}{l}++++ \\
+\end{array}$ & $\begin{array}{l}++++ \\
+\end{array}$ & $\begin{array}{l}++++ \\
+\end{array}$ & $\begin{array}{l}++++ \\
+\end{array}$ & $\begin{array}{l}++++ \\
+\end{array}$ \\
\hline 72 & Cá bống tượng & $\begin{array}{l}\text { Oxyeleotris marmorata } \\
\text { (Bleeker, 1852) }\end{array}$ & $\begin{array}{l}++++ \\
+\end{array}$ & $\begin{array}{l}++++ \\
+\end{array}$ & $\begin{array}{l}++++ \\
+\end{array}$ & ++++ & $\begin{array}{l}++++ \\
+\end{array}$ & ++++ \\
\hline 73 & Cá bống dừa & $\begin{array}{l}\text { Oxyeleotris urophthalmus } \\
\text { (Bleeker, 1851) }\end{array}$ & $\begin{array}{l}++++ \\
+\end{array}$ & $\begin{array}{l}++++ \\
+\end{array}$ & & +++ & $\begin{array}{l}++++ \\
+\end{array}$ & ++ \\
\hline 21 & Họ cá bống trắng & Gobiidae & & & & & & \\
\hline 74 & Cá bống cát & $\begin{array}{l}\text { Glossogobius aureus } \\
\text { Akihito \& Meguro, } 1975\end{array}$ & $\begin{array}{l}++++ \\
+\end{array}$ & $\begin{array}{l}++++ \\
+\end{array}$ & $\begin{array}{l}++++ \\
+\end{array}$ & $\begin{array}{l}++++ \\
+\end{array}$ & ++++ & $\begin{array}{l}++++ \\
+\end{array}$ \\
\hline 75 & Cá bống cát & $\begin{array}{l}\text { Glossogobius giuris } \\
\text { (Hamilton, 1822) }\end{array}$ & $\begin{array}{l}++++ \\
+\end{array}$ & $\begin{array}{l}++++ \\
+\end{array}$ & $\begin{array}{l}++++ \\
+\end{array}$ & $\begin{array}{l}++++ \\
+\end{array}$ & $\begin{array}{l}++++ \\
+\end{array}$ & $\begin{array}{l}++++ \\
+\end{array}$ \\
\hline 76 & Cá bống & $\begin{array}{l}\text { Oligolepis acutipennis } \\
\text { (Valenciennes, 1837) }\end{array}$ & & & + & ++ & ++++ & + \\
\hline 77 & Cá bống & $\begin{array}{l}\text { Stenogobius mekongensis } \\
\text { Watson, } 1991\end{array}$ & +++ & +++ & + & $\begin{array}{l}++++ \\
+\end{array}$ & $\begin{array}{l}++++ \\
+\end{array}$ & + \\
\hline 78 & Cá thòi lòi & $\begin{array}{l}\text { Periophthalmodon } \\
\text { septemradiatus (Hamilton, } \\
1822 \text { ) }\end{array}$ & & & + & & & \\
\hline 79 & $\begin{array}{l}\text { Cá bống kèo vảy } \\
\text { to }\end{array}$ & $\begin{array}{l}\text { Parapocryptes serperaster } \\
\text { (Richardson, 1846) }\end{array}$ & & & + & + & ++ & + \\
\hline 80 & Cá lưỡi búa & $\begin{array}{l}\text { Taenioides gracilis } \\
\text { (Valenciennes, 1837) }\end{array}$ & & & & + & & + \\
\hline 81 & Cá lưỡi búa & $\begin{array}{l}\text { Trypauchenopsis } \\
\text { intermedia Voltz, } 1903\end{array}$ & & & & & + & \\
\hline $\mathrm{XI}$ & BỘ MANG LIỀN & SYNBRANCHIFORMES & & & & & & \\
\hline
\end{tabular}




\begin{tabular}{|c|c|c|c|c|c|c|c|c|}
\hline STT & $\begin{array}{l}\text { TÊN TIÊNG } \\
\text { VIẸT }\end{array}$ & TÊN KHOA HỌC & $\begin{array}{l}\text { Đợt } 1 \\
\text { Tháng } \\
12 / 20 \\
15\end{array}$ & $\begin{array}{l}\text { Đợt } 2 \\
\text { Tháng } \\
02 / 20 \\
16\end{array}$ & $\begin{array}{l}\text { Đợt } 3 \\
\text { Tháng } \\
04 / 20 \\
16\end{array}$ & $\begin{array}{l}\text { Đợt } 4 \\
\text { Tháng } \\
06 / 20 \\
16\end{array}$ & $\begin{array}{l}\text { Đợt } 5 \\
\text { Tháng } \\
08 / 20 \\
16\end{array}$ & $\begin{array}{l}\text { Đợt } 6 \\
\text { Tháng } \\
10 / 20 \\
16\end{array}$ \\
\hline 22 & Họ cá chạch & Mastacembelidae & & & & & & \\
\hline 82 & Cá chạch bông & $\begin{array}{l}\text { Mastacembelus armatus } \\
\text { (Lacepède, 1800) }\end{array}$ & +++ & +++ & ++ & +++ & +++ & ++ \\
\hline 83 & Cá chạch khoang & $\begin{array}{l}\text { Macrognathus } \\
\text { circumcinctus (Hora, } \\
\text { 1924) }\end{array}$ & & & & ++ & & \\
\hline 84 & Cá chạch xiêm & $\begin{array}{l}\text { Macrognathus siamensis } \\
\text { (Günther, 1861) }\end{array}$ & $\begin{array}{l}++++ \\
+\end{array}$ & $\begin{array}{l}++++ \\
+\end{array}$ & +++ & $\begin{array}{l}++++ \\
+\end{array}$ & $\begin{array}{l}++++ \\
+\end{array}$ & ++++ \\
\hline 85 & Cá chạch cơm & $\begin{array}{l}\text { Macrognathus } \\
\text { semiocellatus Roberts, } \\
1986\end{array}$ & ++++ & ++++ & $\begin{array}{l}++++ \\
+\end{array}$ & $\begin{array}{l}\text { l+ } \\
+\end{array}$ & $\begin{array}{l}\text { la } \\
++++ \\
+\end{array}$ & ++ \\
\hline 23 & Họ lươn & Synbranchidae & & & & & & \\
\hline 86 & Lươn & $\begin{array}{l}\text { Monopterus albus (Zuiew. } \\
1793 \text { ) }\end{array}$ & $\begin{array}{l}++++ \\
+\end{array}$ & $\begin{array}{l}++++ \\
+\end{array}$ & $\begin{array}{l}++++ \\
+\end{array}$ & $\begin{array}{l}++++ \\
+\end{array}$ & $\begin{array}{l}++++ \\
+\end{array}$ & $\begin{array}{l}++++ \\
+\end{array}$ \\
\hline 87 & Lich đỏ & Macrotrema sp. & & & & + & & \\
\hline XII & $\begin{array}{l}\text { BỒ CÁ RÔ } \\
\text { ĐỒNG }\end{array}$ & ANABANTIFORMES & & & & & & \\
\hline 24 & Họ cá rô & Anabantidae & & & & & & \\
\hline 88 & Cá rô đồng & $\begin{array}{l}\text { Anabas testudineus } \\
\text { (Bloch, 1792) }\end{array}$ & $\begin{array}{l}++++ \\
+\end{array}$ & $\begin{array}{l}++++ \\
+\end{array}$ & $\begin{array}{l}++++ \\
+ \\
\end{array}$ & $\begin{array}{l}++++ \\
+\end{array}$ & $\begin{array}{l}++++ \\
+ \\
\end{array}$ & $\begin{array}{l}++++ \\
+ \\
\end{array}$ \\
\hline 25 & Họ cá hường & Helostomatidae & & & & & & \\
\hline 89 & Cá hường & $\begin{array}{l}\text { Helostoma temminkii } \\
\text { Cuvier, } 1829\end{array}$ & & & + & & +++ & ++ \\
\hline 26 & Họ cá tai tượng & Osphronemidae & & & & & & \\
\hline 90 & Cá tai tượng & $\begin{array}{l}\text { Osphronemus goramy } \\
\text { Lacepède, } 1801\end{array}$ & + & ++ & ++ & + & +++ & +++ \\
\hline 91 & Cá sặc bướm & $\begin{array}{l}\text { Trichopodus trichopterus } \\
\text { (Pallas, 1770) }\end{array}$ & $\begin{array}{l}++++ \\
+\end{array}$ & $\begin{array}{l}++++ \\
+\end{array}$ & $\begin{array}{l}++++ \\
+ \\
\end{array}$ & $\begin{array}{l}\begin{array}{l}++++ \\
+\end{array} \\
\end{array}$ & $\begin{array}{l}++++ \\
+\end{array}$ & $\begin{array}{l}++++ \\
+ \\
\end{array}$ \\
\hline 92 & Cá sặc rằn & $\begin{array}{l}\text { Trichopodus pectoralis } \\
\text { Regan, } 1910\end{array}$ & ++ & ++ & ++++ & ++++ & $\begin{array}{l}++++ \\
+\end{array}$ & ++++ \\
\hline 93 & Cá sặc điệp & $\begin{array}{l}\text { Trichopodus microlepis } \\
\text { (Günther, 1861) }\end{array}$ & $\begin{array}{l}++++ \\
+\end{array}$ & $\begin{array}{l}++++ \\
+\end{array}$ & $\begin{array}{l}++++ \\
+ \\
\end{array}$ & $\begin{array}{l}++++ \\
+\end{array}$ & $\begin{array}{l}++++ \\
+\end{array}$ & ++++ \\
\hline 94 & Cá bãi trầu & $\begin{array}{l}\text { Trichopsis vittata (Cuvier, } \\
\text { 1831) }\end{array}$ & ++++ & ++++ & ++ & ++ & ++++ & ++++ \\
\hline 95 & Cá lia thia xiêm & $\begin{array}{l}\text { Betta sp. } \\
\text { (cf.mahachaiensis) }\end{array}$ & & & & & & + \\
\hline 27 & Họ cá lóc & Channidea & & & & & & \\
\hline 96 & Cá lóc bông & $\begin{array}{l}\text { Channa micropeltes } \\
\text { (Cuvier, 1831) }\end{array}$ & + & + & + & + & + & + \\
\hline 97 & Cá lóc & $\begin{array}{l}\text { Channa striata (Bloch, } \\
1793 \text { ) }\end{array}$ & $\begin{array}{l}++++ \\
+\end{array}$ & $\begin{array}{l}++++ \\
+\end{array}$ & $\begin{array}{l}++++ \\
+\end{array}$ & $\begin{array}{l}++++ \\
+\end{array}$ & $\begin{array}{l}++++ \\
+\end{array}$ & $\begin{array}{l}++++ \\
+ \\
\end{array}$ \\
\hline 98 & Cá dầy & $\begin{array}{l}\text { Channa lucius (Cuvier, } \\
\text { 1831) }\end{array}$ & +++ & +++ & +++ & ++ & ++++ & +++ \\
\hline 99 & Cá chành dục & $\begin{array}{l}\text { Channa gachua } \\
\text { (Hamilton, 1822) }\end{array}$ & & & & & & + \\
\hline 28 & Họ cá rô biển & Pristolepididae & & & & & & \\
\hline 100 & Cá rô biển & Pristolepis fasciata & ++++ & ++++ & ++++ & ++++ & ++++ & ++++ \\
\hline
\end{tabular}




\begin{tabular}{|c|c|c|c|c|c|c|c|c|}
\hline STT & $\begin{array}{l}\text { TÊN TIẾNG } \\
\text { VIẸT }\end{array}$ & TÊN KHOA HỌC & $\begin{array}{l}\text { Đợt } 1 \\
\text { Tháng } \\
12 / 20 \\
15\end{array}$ & $\begin{array}{l}\text { Đợt } 2 \\
\text { Tháng } \\
02 / 20 \\
16\end{array}$ & $\begin{array}{l}\text { Đợt } 3 \\
\text { Tháng } \\
04 / 20 \\
16\end{array}$ & $\begin{array}{l}\text { Đợt } 4 \\
\text { Tháng } \\
06 / 20 \\
16\end{array}$ & $\begin{array}{l}\text { Đợt } 5 \\
\text { Tháng } \\
08 / 20 \\
16\end{array}$ & $\begin{array}{l}\text { Đợt } 6 \\
\text { Tháng } \\
10 / 20 \\
16\end{array}$ \\
\hline & & (Bleeker, 1851) & + & + & + & + & + & + \\
\hline XIII & BỘ CÁ BƠN & PLEURONECTIFORMES & & & & & & \\
\hline 29 & Họ cá bơn sọc & Soleidae & & & & & & \\
\hline 101 & Cá lưỡi mèo & $\begin{array}{l}\text { Brachirus elongatus } \\
\text { (Pellegrin \& Chevey, } \\
1940 \text { ) }\end{array}$ & ++ & ++ & + & + & + & \\
\hline 102 & Cá lưỡi mèo & $\begin{array}{l}\text { Brachirus harmandi } \\
\text { (Sauvage, 1878) }\end{array}$ & ++ & ++ & + & + & + & \\
\hline 103 & Cá lưỡi mèo & $\begin{array}{l}\text { Brachirus panoides } \\
\text { (Bleeker, 1851) }\end{array}$ & $\begin{array}{l}++++ \\
+\end{array}$ & $\begin{array}{l}++++ \\
+\end{array}$ & ++++ & ++ & $\begin{array}{l}++++ \\
+ \\
\end{array}$ & +++ \\
\hline 30 & Họ cá bơn lưỡi bò & Cynoglossidae & & & & & & \\
\hline 104 & $\begin{array}{l}\text { Cá lưỡi trâu vảy } \\
\text { nhỏ }\end{array}$ & $\begin{array}{l}\text { Cynoglossus microlepis } \\
\text { (Bleeker, 1851) }\end{array}$ & ++++ & +++ & $\begin{array}{l}++++ \\
+\end{array}$ & +++ & ++++ & $\begin{array}{l}++++ \\
+\end{array}$ \\
\hline 105 & Cá bơn vằn & $\begin{array}{l}\text { Cynoglossus puncticeps } \\
\text { (Richardson, 1846) }\end{array}$ & +++ & +++ & $\begin{array}{l}++++ \\
+ \\
\end{array}$ & ++ & + & + \\
\hline 106 & Cá bơn & $\begin{array}{l}\text { Cynoglossus trulla } \\
\text { (Cantor, 1849) }\end{array}$ & ++ & ++ & + & & & \\
\hline XIV & BỘ CÁ RÔ PHI & CICHLIFORMES & & & & & & \\
\hline 31 & Họ cá rô phi & Cichlidae & & & & & & \\
\hline 107 & Cá rô phi & $\begin{array}{l}\text { Oreochromis niloticus } \\
\text { (Linnaeus, 1758) }\end{array}$ & $\begin{array}{l}++++ \\
+\end{array}$ & $\begin{array}{l}++++ \\
+\end{array}$ & $\begin{array}{l}++++ \\
+\end{array}$ & $\begin{array}{l}++++ \\
+\end{array}$ & $\begin{array}{l}++++ \\
+\end{array}$ & $\begin{array}{l}++++ \\
+\end{array}$ \\
\hline $\mathrm{XV}$ & BỘ CÁ SÓC & $\begin{array}{l}\text { CYPRINODONTIFORM } \\
\text { ES }\end{array}$ & & & & & & \\
\hline 32 & Họ cá bạc đầu & Aplocheilidae & & & & & & \\
\hline 108 & Cá bạc đầu & $\begin{array}{l}\text { Aplocheilus panchax } \\
\text { (Hamilton, 1822) }\end{array}$ & & & & & & + \\
\hline XVI & BỘ CÁ NHÓI & BELONIFORMES & & & & & & \\
\hline 33 & Họ cá nhái & Belonidae & & & & & & \\
\hline 109 & Cá nhái đuôi chấm & $\begin{array}{l}\text { Strongylura strongylura } \\
\text { (van Hasselt, 1823) }\end{array}$ & & & & + & & \\
\hline 34 & Họ cá lìm kìm & Hemiramphidae & & & & & & \\
\hline 110 & Cá kìm bên & $\begin{array}{l}\text { Hyporhamphus limbatus } \\
\text { (Valenciennes, 1847) }\end{array}$ & & & + & + & + & + \\
\hline 111 & Cá lìm kìm ao & $\begin{array}{l}\text { Dermogenys siamensis } \\
\text { Fowler, } 1934\end{array}$ & + & + & + & ++ & ++ & ++ \\
\hline $\begin{array}{l}\text { XVI } \\
\text { I }\end{array}$ & BỘ CÁ ĐỐI & MUGILIFORMES & & & & & & \\
\hline 35 & Họ cá đối & Mugilidae & & & & & & \\
\hline 112 & Cá đối đất & $\begin{array}{l}\text { Chelon subviridis } \\
\text { (Valenciennes, 1836) }\end{array}$ & & + & + & + & +++ & +++ \\
\hline $\begin{array}{l}\text { XVI } \\
\text { II }\end{array}$ & BỘ CÁ NÓC & $\begin{array}{l}\text { TETRAODONTIFORME } \\
\mathrm{S}\end{array}$ & & & & & & \\
\hline 36 & Họ cá nóc & Tetraodontidae & & & & & & \\
\hline 113 & Cá nóc & $\begin{array}{l}\text { Tetraodon cochinchinensis } \\
\text { (Steindachner, 1866) }\end{array}$ & ++++ & +++ & +++ & + & & \\
\hline XIX & BÔ CÁ VƯƠC & PERCIFORMES & & & & & & \\
\hline 37 & Họ cá sơn & Ambassidae & & & & & & \\
\hline
\end{tabular}


100 L.K. Ngọc và nnk. / Tạp chí Khoa học ĐHQGHN: Khoa học Tụ nhiên và Công nghệ, Tập 34, Số 1 (2018) 90-104

\begin{tabular}{|c|c|c|c|c|c|c|c|c|}
\hline STT & $\begin{array}{l}\text { TÊN TIÊNG } \\
\text { VIẸT }\end{array}$ & TÊN KHOA HỌC & $\begin{array}{l}\text { Đợt } 1 \\
\text { Tháng } \\
12 / 20 \\
15\end{array}$ & $\begin{array}{l}\text { Đợt } 2 \\
\text { Tháng } \\
02 / 20 \\
16\end{array}$ & $\begin{array}{l}\text { Đợt } 3 \\
\text { Tháng } \\
04 / 20 \\
16\end{array}$ & $\begin{array}{l}\text { Đợt } 4 \\
\text { Tháng } \\
06 / 20 \\
16\end{array}$ & $\begin{array}{l}\text { Đợt } 5 \\
\text { Tháng } \\
08 / 20 \\
16\end{array}$ & $\begin{array}{l}\text { Đợt } 6 \\
\text { Tháng } \\
10 / 20 \\
16\end{array}$ \\
\hline 114 & Cá sơn bầu & $\begin{array}{l}\text { Parambassis wolffii } \\
\text { (Bleeker, 1850) }\end{array}$ & $\begin{array}{l}++++ \\
+\end{array}$ & $\begin{array}{l}++++ \\
+\end{array}$ & $\begin{array}{l}++++ \\
+\end{array}$ & $\begin{array}{l}++++ \\
+\end{array}$ & $\begin{array}{l}++++ \\
+\end{array}$ & $\begin{array}{l}++++ \\
+\end{array}$ \\
\hline 38 & Họ cá chẽm & Latidae & & & & & & \\
\hline 115 & Cá chẽm & $\begin{array}{l}\text { Lates calcarifer (Bloch, } \\
1790)\end{array}$ & + & + & + & + & ++ & + \\
\hline 39 & Họ cá liệt & Leiognathidae & & & & & & \\
\hline 116 & Cá liệt mõm ngắn & $\begin{array}{l}\text { Nuchequula gerreoides } \\
\text { (Bleeker, 1851) }\end{array}$ & & & + & + & & \\
\hline 117 & Cá liệt lớn & $\begin{array}{l}\text { Leiognathus equulus } \\
\text { (Forsskål, 1775) }\end{array}$ & & & & + & & \\
\hline 40 & Họ cá hường vện & Lobotidae & & & & & & \\
\hline 118 & Cá hường vện & $\begin{array}{l}\text { Datnioides polota } \\
\text { (Hamilton, 1822) }\end{array}$ & + & + & ++ & $\begin{array}{l}++++ \\
+\end{array}$ & ++++ & ++ \\
\hline 41 & Họ cá móm & Gerreidae & & & & & & \\
\hline 119 & Cá móm & $\begin{array}{l}\text { Gerres decacanthus } \\
\text { (Bleeker, 1864) }\end{array}$ & & & & + & + & \\
\hline 42 & Họ cá lù đù & Sciaenidae & & & & & & \\
\hline 120 & Cá sửu & $\begin{array}{l}\text { Boesemania microlepis } \\
\text { (Bleeker, 1858) }\end{array}$ & & & $\begin{array}{l}++++ \\
+\end{array}$ & ++++ & $\begin{array}{l}++++ \\
+\end{array}$ & ++++ \\
\hline 43 & Họ cá nhụ & Polynemidae & & & & & & \\
\hline 121 & Cá phèn vàng & $\begin{array}{l}\text { Polynemus melanochir } \\
\text { Valenciennes, } 1831\end{array}$ & $\begin{array}{l}++++ \\
+ \\
\end{array}$ & $\begin{array}{l}++++ \\
+ \\
\end{array}$ & $\begin{array}{l}++++ \\
+ \\
\end{array}$ & $\begin{array}{l}++++ \\
+ \\
\end{array}$ & $\begin{array}{l}++++ \\
+ \\
\end{array}$ & $\begin{array}{l}++++ \\
+ \\
\end{array}$ \\
\hline 122 & Cá phèn trắng & $\begin{array}{l}\text { Polynemus aquilonaris } \\
\text { Motomura, } 2003\end{array}$ & & & & & + & \\
\hline 44 & Họ cá mang rổ & Toxotidae & & & & & & \\
\hline 123 & Cá mang rổ & $\begin{array}{l}\text { Toxotes chatareus } \\
\text { (Hamilton, 1822) }\end{array}$ & +++ & ++ & + & + & + & ++ \\
\hline 45 & Họ cá đàn lia & Callionymidae & & & & & & \\
\hline 124 & Cá đàn lia & $\begin{array}{l}\text { Tonlesapia tsukawakii } \\
\text { Motomura \& Mukai, } 2006\end{array}$ & + & + & + & + & + & + \\
\hline 46 & Họ cá nâu & Scatophagidae & & & & & & \\
\hline 125 & Cá nâu & $\begin{array}{l}\text { Scatophagus argus } \\
\text { (Linnaeus, 1766) }\end{array}$ & & & + & + & + & \\
\hline
\end{tabular}

Ghi chú: *loài lai giữa cá trê trắng và cá trê phi; +: xuất hiện 1 lần/đợt thu mẫu; ++: xuất hiện 2 lần/đợt thu mẫu; +++: xuất hiện 3 lần/đọt thu mẫu; ++++: xuất hiện 4 lần/đợt mẫu; +++++: xuất hiện $\geq 5$ lần/đợt thu mẫu.

Số lượng và tỉ lệ \% các họ và loài thuộc 15 bộ cá ở tỉnh Hậu Giang được thể hiện ở Bảng 2.

Bảng 2. Thông tin về số lượng loài cá thu được ở tỉnh Hậu Giang từ 12/2015 đến 11/2016

\begin{tabular}{|c|c|c|c|c|c|c|c|c|c|c|c|}
\hline \multirow[b]{2}{*}{$\begin{array}{l}\mathrm{ST} \\
\mathrm{T}\end{array}$} & \multirow[b]{2}{*}{$\begin{array}{l}\text { Tên tiếng } \\
\text { việt }\end{array}$} & \multirow[b]{2}{*}{ Tên khoa học } & \multicolumn{3}{|c|}{ Toàn tỉnh } & \multicolumn{6}{|l|}{ Số loài } \\
\hline & & & $\begin{array}{l}\text { Số } \\
\text { họ }\end{array}$ & $\begin{array}{l}\text { Số } \\
\text { loài }\end{array}$ & $\begin{array}{l}\text { Tỷ } \\
\text { lệ } \\
\text { loài } \\
(\%) \\
\end{array}$ & $\begin{array}{l}\text { Đơt } 1 \\
\text { Tháng } \\
12 / 201 \\
5 \\
\end{array}$ & $\begin{array}{l}\text { Đợt } 2 \\
\text { Tháng } \\
02 / 201 \\
6 \\
\end{array}$ & $\begin{array}{l}\text { Đợt } 3 \\
\text { Tháng } \\
04 / 201 \\
6 \\
\end{array}$ & $\begin{array}{l}\text { Đợt } 4 \\
\text { Tháng } \\
06 / 201 \\
6 \\
\end{array}$ & $\begin{array}{l}\text { Đợt } 5 \\
\text { Tháng } \\
08 / 201 \\
6\end{array}$ & $\begin{array}{l}\text { Đợt } 6 \\
\text { Tháng } \\
10 / 201 \\
6\end{array}$ \\
\hline 1 & Bộ cá chình & Anguilliiformes & 1 & 2 & 1,6 & 0 & 0 & 1 & 2 & 0 & 2 \\
\hline 2 & $\begin{array}{l}\text { Bộ cá thát } \\
\text { lát }\end{array}$ & $\begin{array}{l}\text { Osteoglossiform } \\
\text { es }\end{array}$ & 1 & 2 & 1,6 & 2 & 2 & 2 & 2 & 2 & 2 \\
\hline
\end{tabular}




\begin{tabular}{|c|c|c|c|c|c|c|c|c|c|c|c|}
\hline \multirow[b]{2}{*}{$\begin{array}{l}\text { ST } \\
\text { T }\end{array}$} & \multirow[b]{2}{*}{$\begin{array}{l}\text { Tên tiếng } \\
\text { việt }\end{array}$} & \multirow[b]{2}{*}{ Tên khoa học } & \multicolumn{3}{|c|}{ Toàn tỉnh } & \multicolumn{6}{|l|}{ Số loài } \\
\hline & & & $\begin{array}{l}\text { Số } \\
\text { họ }\end{array}$ & $\begin{array}{l}\text { Số } \\
\text { loài }\end{array}$ & $\begin{array}{l}\text { Tỷ } \\
\text { lệ } \\
\text { loài } \\
(\%) \\
\end{array}$ & $\begin{array}{l}\text { Đợt } 1 \\
\text { Tháng } \\
12 / 201 \\
5\end{array}$ & $\begin{array}{l}\text { Đợt } 2 \\
\text { Tháng } \\
02 / 201 \\
6\end{array}$ & $\begin{array}{l}\text { Đợt } 3 \\
\text { Tháng } \\
04 / 201 \\
6\end{array}$ & $\begin{array}{l}\text { Đợt } 4 \\
\text { Tháng } \\
06 / 201 \\
6\end{array}$ & $\begin{array}{l}\text { Đơt } 5 \\
\text { Tháng } \\
08 / 201 \\
6\end{array}$ & $\begin{array}{l}\text { Đợt } 6 \\
\text { Tháng } \\
\text { 10/201 } \\
6\end{array}$ \\
\hline 3 & Bộ cá trích & Clupeiformes & 2 & 6 & 4,8 & 4 & 4 & 6 & 5 & 4 & 5 \\
\hline 4 & Bộ cá chép & Cypriniformes & 3 & 30 & 24,0 & 19 & 19 & 20 & 23 & 23 & 22 \\
\hline 5 & Bộ cá chim & Characiformes & 1 & 1 & 0,8 & 1 & 1 & 0 & 0 & 0 & 1 \\
\hline 6 & $\begin{array}{l}\text { Bộ cá da } \\
\text { trơn }\end{array}$ & Siluriformes & 8 & 25 & 20,0 & 15 & 16 & 19 & 22 & 24 & 19 \\
\hline 7 & $\begin{array}{l}\text { Bộ cá hàm } \\
\text { ếch }\end{array}$ & $\begin{array}{l}\text { Batrachoidiform } \\
\text { es }\end{array}$ & 1 & 1 & 0,8 & 0 & 0 & 1 & 1 & 0 & 1 \\
\hline 8 & $\begin{array}{l}\text { Bộ cá thu } \\
\text { ngừ }\end{array}$ & Scombriformes & 1 & 1 & 0,8 & 0 & 0 & 0 & 1 & 0 & 0 \\
\hline 9 & $\begin{array}{l}\text { Bộ cá chìa } \\
\text { vôi }\end{array}$ & $\begin{array}{l}\text { Gasterosteiforme } \\
\mathrm{s}\end{array}$ & 1 & 1 & 0,8 & 0 & 0 & 1 & 0 & 0 & 0 \\
\hline 10 & Bộ cá bống & Gobiformes & 2 & 12 & 9,6 & 6 & 7 & 9 & 9 & 10 & 10 \\
\hline 11 & $\begin{array}{l}\text { Bộ mang } \\
\text { liền }\end{array}$ & $\begin{array}{l}\text { Synbranchiform } \\
\text { es }\end{array}$ & 2 & 6 & 4,8 & 4 & 4 & 4 & 6 & 4 & 4 \\
\hline 12 & $\begin{array}{l}\text { Bộ cá rô } \\
\text { dồng }\end{array}$ & Anabatiformes & 5 & 13 & 10,4 & 10 & 10 & 11 & 10 & 11 & 13 \\
\hline 13 & Bộ cá bơn & $\begin{array}{l}\text { Pleuronectiform } \\
\text { es }\end{array}$ & 2 & 6 & 4,8 & 6 & 6 & 6 & 5 & 5 & 3 \\
\hline 14 & Bộ cá rô phi & Cichliformes & 1 & 1 & 0,8 & 1 & 1 & 1 & 1 & 1 & 1 \\
\hline 15 & Bộ cá sóc & $\begin{array}{l}\text { Cyprinodontifor } \\
\text { mes }\end{array}$ & 1 & 1 & 0,8 & 0 & 0 & 0 & 0 & 0 & 1 \\
\hline 16 & Bộ cá nhói & Beloniformes & 2 & 3 & 2,4 & 1 & 1 & 2 & 3 & 2 & 2 \\
\hline 17 & Bộ cá đối & Mugiliformes & 1 & 1 & 0,8 & 0 & 1 & 1 & 1 & 1 & 1 \\
\hline 18 & Bộ cá nóc & $\begin{array}{l}\text { Tetraodontiform } \\
\text { es }\end{array}$ & 1 & 1 & 0,8 & 1 & 1 & 1 & 1 & 0 & 0 \\
\hline 19 & Bộ cá vược & Perciformes & 10 & 12 & 9,6 & 6 & 6 & 9 & 11 & 10 & 7 \\
\hline Tổn & cộng & & 46 & 125 & $\begin{array}{l}100 \\
0\end{array}$ & 76 & 79 & 94 & 103 & 97 & 94 \\
\hline
\end{tabular}

Kết quả phân tích cho thấy có tổng số 125 loài đã được ghi nhận ở lưu vực sông Hậu thuộc địa phận tỉnh Hậu Giang. Về bậc họ, cá vược là bộ có nhiều họ nhất (10 họ), tiếp đến là bộ cá da trơn ( 8 họ), bộ cá rô đồng ( 5 họ), bộ cá chép (3 họ) và các bộ còn lại có từ $1-2$ họ. Về bậc loài, cá chép là bộ có nhiều loài nhất với 30 loài (24\%), bộ cá da trơn với 25 loài (20\%), tiếp đến là bộ cá rô đồng với 13 loài $(10,4 \%)$, bộ cá vược với 12 loài $(9,6 \%)$ và bộ cá bống mặc dù chỉ có 2 họ nhưng cũng khá đa dạng về thành phần loài (12 loài). Năm bộ này có nhiều loài xuất hiện với tần số cao.

Tương tự, khi xét riêng từng đợt thu mẫu thì 5 bộ cá chép, cá da trơn, cá rô đồng, cá vược, và cá bống đều có thành phần loài nhiều hơn so với những bộ còn lại. Điều này còn tìm thấy khi xét theo mùa (mùa khô từ tháng 11/2015 đến tháng 4/2016 ứng với đợt thu mẫu 1,2 và 3 ; mùa mưa từ tháng $5 / 2016$ đến tháng $10 / 2016$ ứng với đợt thu mẫu 4,5 và 6 ). Khi xét tổng thể thì mùa mưa có thành phần loài (119 loài) cao hơn so với mùa mùa khô (101 loài). Trong đó, ở đợt thu mẫu thứ 4 tương ứng vào thời điểm tháng 6/2016 (đầu mùa mưa) thu được nhiều loài nhất (103 loài) trong 6 đợt thu mẫu. Điều này có thể do vào mùa mưa hệ thống sông, kênh rạch trên địa bàn tỉnh Hậu Giang nhận nguồn nước từ thượng nguồn đổ về và có khả năng nhiều loài cá ở vùng thượng nguồn đi theo con nước di cư đến khu vực hạ nguồn trong đó có tỉnh Hậu Giang, góp phần làm phong phú thêm thành phần loài cá ở đây. 
Thành phần loài cá phân bố ở 3 vùng sinh thể hiện ở Hình 2. thái trong tỉnh cũng có sự khác nhau và được

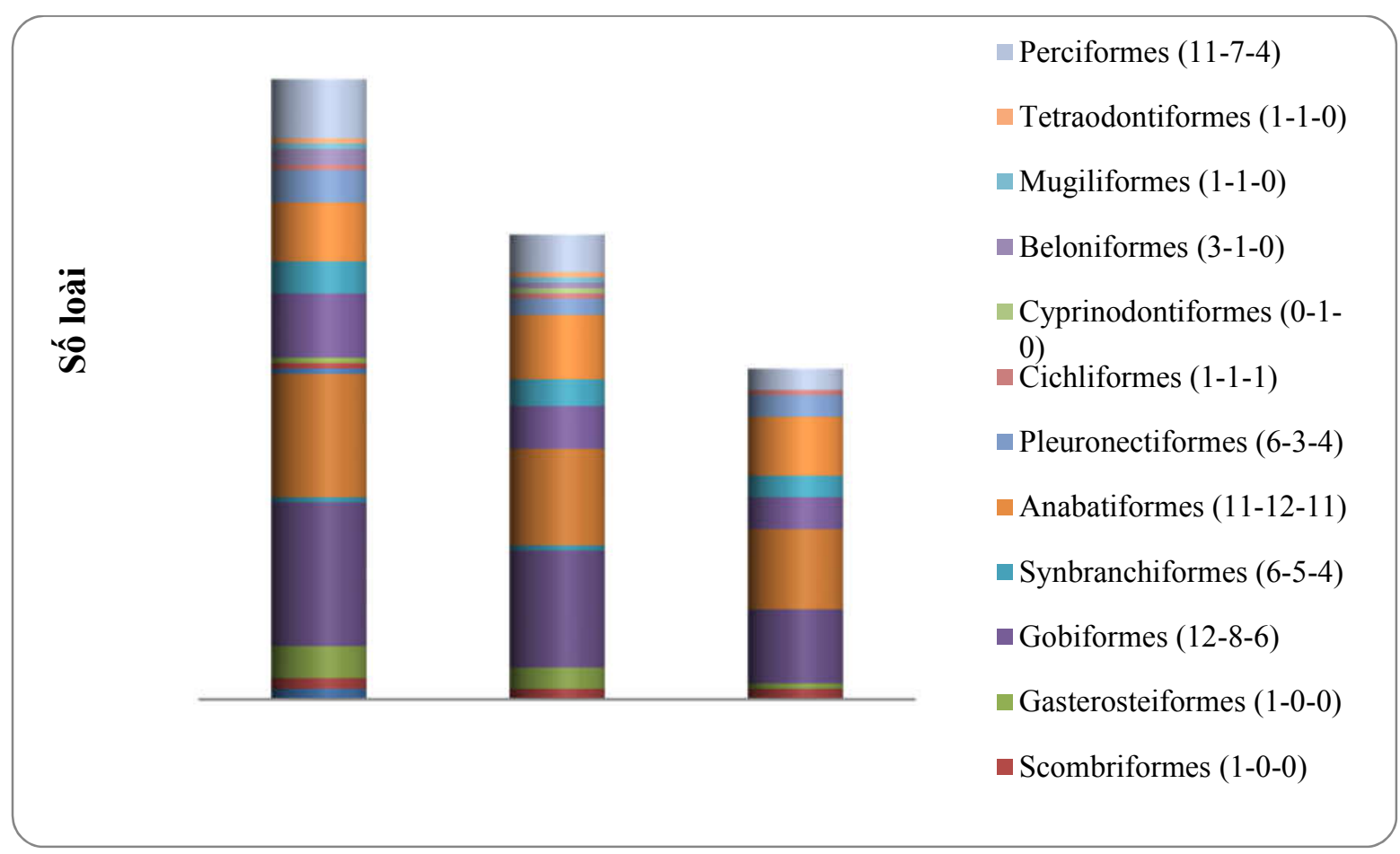

Hình 2. Số lượng loài cá theo bộ ở 3 vùng sinh thái trong tỉnh Hậu Giang. Các giá trị trong dấu ngoặc đơn ở mỗi Bộ cho thấy số lượng loài ở từng vùng sinh thái I, II và III.

Vùng I (vùng chịu ảnh hưởng của triều biển Đông) có thành phần loài đa dạng nhất, với 116 loài thuộc 18 bộ và 44 họ, thể hiện được nét đa dạng thành phần loài của tỉnh Hậu Giang. Trong đó, bộ cá chép có 27 loài, chiểm 23,3\%; bộ cá da trơn có 23 loài, chiếm $19,8 \%$; bộ cá bống có 12 loài chiếm $10,3 \%$; bộ cá rô đồng và bộ cá vược có cùng số loài là 11 loài, chiếm $9,5 \%$; các bộ còn lại có 32 loài, mỗi bộ có từ 16 loài.

Với đặc thù điều kiện tự nhiên ở vùng I chịu ảnh hưởng của thủy triều biển Đông (chế độ bán nhật triều), dòng chảy mạnh, chênh lệch mực nước giữa con nước lớn và ròng trong ngày cao hơn so với những vùng khác trong tỉnh; vùng này còn có nhiều sông lớn, đặc biệt là có đoạn sông Hậu chảy qua. Đây là con sông thuộc vùng hạ lưu của dòng sông Mekong, hàng năm vào mùa nước nổi con sông đã tiếp nhận nước từ thượng nguồn đổ về mang theo nhiều tôm, cá. Vì vậy, vào thời điểm mùa mưa cũng trùng vào mùa nước nổi, nơi đây có số lượng loài thủy sản phong phú hơn so với mùa khô. Thêm vào đó, năm 2016 là năm ĐBSCL phải hứng chịu một đợt hạn - mặn lịch sử chưa từng có [15] và khu vực của tỉnh Hậu Giang cũng bị ảnh hưởng bởi mặn. Do đó, vào khoảng tháng 2-3/2016 là thời điểm mặn xâm nhập sâu nhất với nồng độ mặn cao đã có một số loài thủy sản vùng nước lợ (cá thu sông, cá nâu, cá chẽm, cá bống kèo vảy to...) theo con nước di cư vào sông Hậu, góp phần cho sự đa dạng thành phần loài trong vùng này.

Vùng II (vùng chịu ảnh hưởng của chế độ nhật triều biển Tây) có thành phần loài ít hơn so với vùng $\mathrm{I}$, với 87 loài thuộc 15 bộ và 36 họ. Trong đó, bộ cá chép có 22 loài, chiếm $25,3 \%$; bộ cá da trơn có 18 loài, chiếm 20,7\%; bộ cá rô 
đồng có 12 loài, chiếm 13,8\%; bộ cá bống có 8 loài, chiếm $9,2 \%$; bộ cá vược có 7 loài, chiếm $8,0 \%$ và các bộ còn lại có 20 loài, mỗi bộ có từ 1-5 loài. Vùng III (vùng tiếp giáp giữa vùng ảnh hưởng của triều biển Đông và triều biển Tây) có thành phần loài ít nhất, với 62 loài thuộc 10 bộ và 26 họ. Trong đó, bộ cá da trơn có 15 loài, chiếm $24,2 \%$; bộ cá chép có 14 loài, chiếm $22,6 \%$; bộ cá rô đồng có 11 loài, chiếm 17,7\%; bộ cá bống có 6 loài, chiếm $9,7 \%$ và các bộ còn lại có 16 loài, mỗi bộ có từ 1-4 loài. Những loài cá ở vùng II và vùng III chủ yếu vẫn là những loài có khả năng thích nghi với điều kiện nước phèn, dòng chảy kém.

\section{Kết luận}

Nghiên cứu này đã ghi nhận được 125 loài cá phân bố ở lưu vực sông Hậu thuộc địa phận tỉnh Hậu Giang. Thành loài cá ở khu vực này phong phú và đa dạng. Mùa mưa có thành phần loài cao hơn so với mùa khô và tháng 6 là thời gian thu được nhiều loài cá nhất. Các bộ cá chép, cá da trơn, cá rô đồng, cá vược và cá bống có thành phần loài nhiều nhất và có nhiều loài xuất hiện với số lượng cá thể rất cao. Vùng sinh thái chịu ảnh hưởng của thủy triều biển Đông có thành phần loài cao hơn so với vùng sinh thái chịu ảnh hưởng của thủy triều biển Tây và vùng sinh thái tiếp giáp giữa 2 vùng trên.

\section{Lời cảm ơn}

Nhóm tác giả xin chân thành cảm ơn Sở Khoa học và Công nghệ tỉnh Hậu Giang đã cấp kinh phí, Sở Nông nghiệp và Phát triển nông thôn tỉnh Hậu Giang đã tạo mọi điều kiện thuận lợi trong suốt quá trình thực hiện; cám ơn các cán bộ ở Trạm thủy sản huyện Châu Thành, Trạm thủy sản Thị xã Ngã Bảy và ngư dân địa phương đã hỗ trợ trong việc thu mẫu cho đề tài "Nghiên cứu, đánh giá nguồn lợi thủy sản trên địa bàn tỉnh Hậu Giang, đề xuất giải pháp bảo vệ và phát triển".

\section{Tài liệu tham khảo}

[1] Vũ Vi An, Đoàn Văn Tiến, Lâm Phước Khiêm \& Nguyễn Nguyễn Du, Đánh giá sản lượng khai thác của ngư dân vùng Đồng bằng sông Cửu Long, Tuyển tập Nghề cá sông Cửu Long, 428-436, 2011.

[2] Mai Đình Yên, Nguyễn Văn Trọng, Nguyễn Văn Thiện, Lê Hoàng Yến \& Hứa Bạch Loan, Định loại cá nước ngọt Nam bộ, Nxb Khoa học và Kỹ thuật, Hà Nội, 1992.

[3] Trương Thủ Khoa \& Trần Thị Thu Hương, Định loại cá nước ngọt vùng Đồng bằng sông Cửu Long, Tủ sách Đại học Cần Thơ, Cần Thơ, 1993.

[4] Đoàn Văn Tiến \& Mai Thị Trúc Chi, Quan Trắc sản lượng cá đánh bắt ở Đồng bằng sông Cửu Long, Hội thảo quốc gia về phát triển thủy sản vùng hạ lưu sông Mekong, Việt nam, Nxb Nông nghiệp, 2005.

[5] Trần Đắc Định, Koichi, S., Nguyễn Thanh Phương, Hà Phước Hùng, Trần Xuân Lợi, Mai Văn Hiếu \& Kenzo, U., Mô tả định loại cá Đồng bằng sông Cửu Long, Việt Nam, Nxb Đại học Cần Thơ, Cần Thơ, 2013.

[6] Viện Quy hoạch thủy lợi miền Nam, Quy hoạch xây dựng thủy lợi tỉnh Hậu Giang đến năm 2020 và tầm nhìn đến năm 2030 (Tập 1 Báo cáo tổng hợp), Thành phố Hồ Chí Minh, 2012.

[7] Phạm Nhật, Vũ Văn Dũng, Đỗ Quang Huy, Nguyễn Cử, Lê Nguyên Ngật, Nguyễn Hữu Dực, Nguyễn Thế Nhã, Võ Sĩ Tuấn, Phan Nguyên Hồng, Nguyễn Văn Tiến, Đào Tấn Hổ, Nguyễn Xuân Hòa, Nick Cox \& Nguyễn Tiến Hiệp, Sổ tay hướng dẫn điều tra và giám sát đa dạng sinh học, Nxb Giao thông vận tải, Hà Nội, 2003.

[8] Pravdin, I. F., Hướng dẫn nghiên cứu cá (Phạm Thị Minh Giang dịch), Nxb Khoa học và Kỹ thuật, Hà Nội, 1973.

[9] Nguyễn Văn Hảo \& Ngô Sỹ Vân, Cá nước ngọt Việt Nam, tập 1 Họ cá chép, Nxb Nông Nghiệp, Hà Nội, 2001.

[10] Nguyễn Văn Hảo, Cá nước ngọt Việt Nam, tập 2, Nxb Nông nghiệp, Hà Nội, 2005.

[11] Nguyễn Văn Hảo, Cá nước ngọt Việt Nam, tập 3, Nxb Nông nghiệp, Hà Nội, 2005.

[12] Rainboth, W. J., Fishes of the Cambodian Mekong, FAO, Roma, 1996.

[13] Froese, R. \& Pauly, D., FishBase, World Wide Web electronic publication, 2017, truy cập ngày 10/06/2017. www.fishbase.org

[14] Fong, William N. Eschmeyer and Jon David, Species by family/subfamily in the Catalog of 
fishes, online version, updated 2 March 2018, Institute for Biodiversity Science and Sustainability, California Academy Sciences, 2018, http://researcharchive.calacademy.org/ research/ichthyology/catalog/SpeciesByFamily.as p.
[15] Nguyễn Ngọc Anh, Hạn - mặn lịch sử năm 2016 ở Đồng bằng sông Cửu Long: bài học kinh nghiệm và những giải pháp ứng phó, Tạp chí Khoa học và Công nghệ Việt Nam, Hà Nội, 19/01/2018, http://www.khoahocvacongnghevietnam.com.vn/k hcn-trung-uong/13123-han-man-lich-su-2016-0dong-bang-song-cuu-long-bai-hoc-kinh-nghiemva-giai-phap-ung-pho.

\title{
Fish Species Composition in Hau River Basin at Hau Giang Province
}

\author{
Le Kim Ngoc ${ }^{1}$, Son Ngoc Huyen ${ }^{1}$, Nguyen Thi Ngoc Hue ${ }^{1}$, \\ Le Hoang Anh ${ }^{1}$, Tran Van Dep ${ }^{1}$, Nguyen Thanh Dong ${ }^{1}$, Tran Dac Dinh ${ }^{2}$, \\ Ha Phuoc Hung 2 , To Thi My Hoang ${ }^{2}$, Nguyen Thi Vang ${ }^{2}$, Vo Thanh Toan ${ }^{2}$, \\ Nguyen Trung Tin ${ }^{2}$, Dinh Minh Quang ${ }^{3}$
}

\author{
${ }^{1}$ Department of Agriculture and Rural Hau Giang, No. 5, Xo Viet Nghe Tinh, Vi Thanh, Hau Giang \\ ${ }^{2}$ College of Aquaculture and Fisheries, Can Tho University, Xuan Khanh, Ninh Kieu, Can Tho, Vietnam \\ ${ }^{3}$ School of Education, Can Tho University, Xuan Khanh, Ninh Kieu, Can Tho, Vietnam
}

\begin{abstract}
This study was conducted from December 2015 to November 2016 at 44 sampling sites in the Hau River Basin at Hau Giang Province. The analysis results recorded 125 fish species belonging to 19 Orders and 46 families. The fish species composition was more diverse in wet season (119 species) than that in dry season (101 species). Of 19 orders, Cypriniformes, Siluriformes, Anabatiformes, Perciformes and Gobiformes had the highest number of species recorded during wet and dry seasons. The fish species composition had higher diversity in the ecological region regulated by east sea tide than the ecological region regulated by west sea tide and the contiguous ecological region.
\end{abstract}

Keyword: fish species composition, Hau Giang, Hau river 